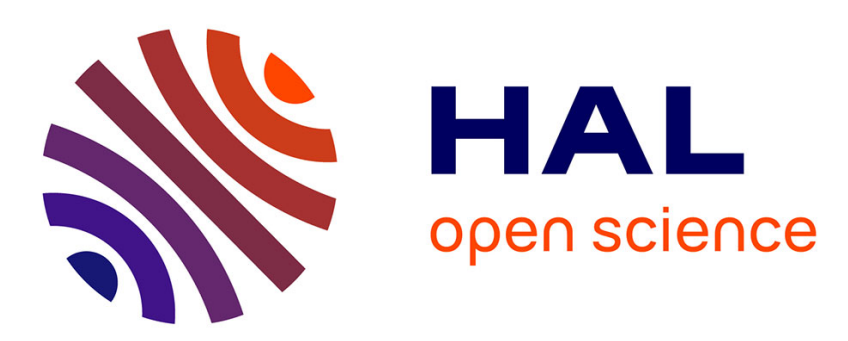

\title{
Probing models of minimal swimming vehicules in vivo with microalgae phototaxis.
}

\author{
David Colliaux, Lia Giraud, Claude Yéprémian, Pierre Bessière, Jacques
}

Droulez

\section{- To cite this version:}

David Colliaux, Lia Giraud, Claude Yéprémian, Pierre Bessière, Jacques Droulez. Probing models of minimal swimming vehicules in vivo with microalgae phototaxis.. European Conference on Artificial Life 2015, Jul 2015, York, United Kingdom. , 2015, 10.7551/978-0-262-33027-5-ch079 hal-01181141

\author{
HAL Id: hal-01181141 \\ https://hal.science/hal-01181141
}

Submitted on 29 Jul 2015

HAL is a multi-disciplinary open access archive for the deposit and dissemination of scientific research documents, whether they are published or not. The documents may come from teaching and research institutions in France or abroad, or from public or private research centers.
L'archive ouverte pluridisciplinaire HAL, est destinée au dépôt et à la diffusion de documents scientifiques de niveau recherche, publiés ou non, émanant des établissements d'enseignement et de recherche français ou étrangers, des laboratoires publics ou privés. 


\section{Probing models of minimal swimming vehicules}

Q in vivo with microalgae phototaxis.

David Colliaux ${ }^{1}$, Lia Giraud ${ }^{2}$, Claude Yéprémian ${ }^{3}$, Pierre Bessiêre ${ }^{1}$ and Jacques Droulez ${ }^{1}$

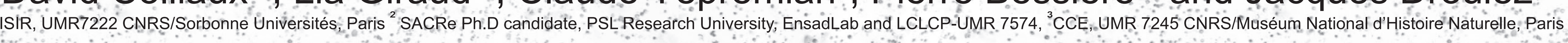

\section{Motivations}

- Unicellular algae, like Chlamydomonas Reinhardtii, are living examples of microscopic phototactic vehicles [1,2]

- The study of their swimming behavior at single cell and population levels unveils properties of their sensorimotor system.

- Microrobots operating in a low Reynolds number regime would benefit from the understanding of their living counterparts.

\section{Characterization}

The density of cells $(A)$ is monitored through the gray level intensities:
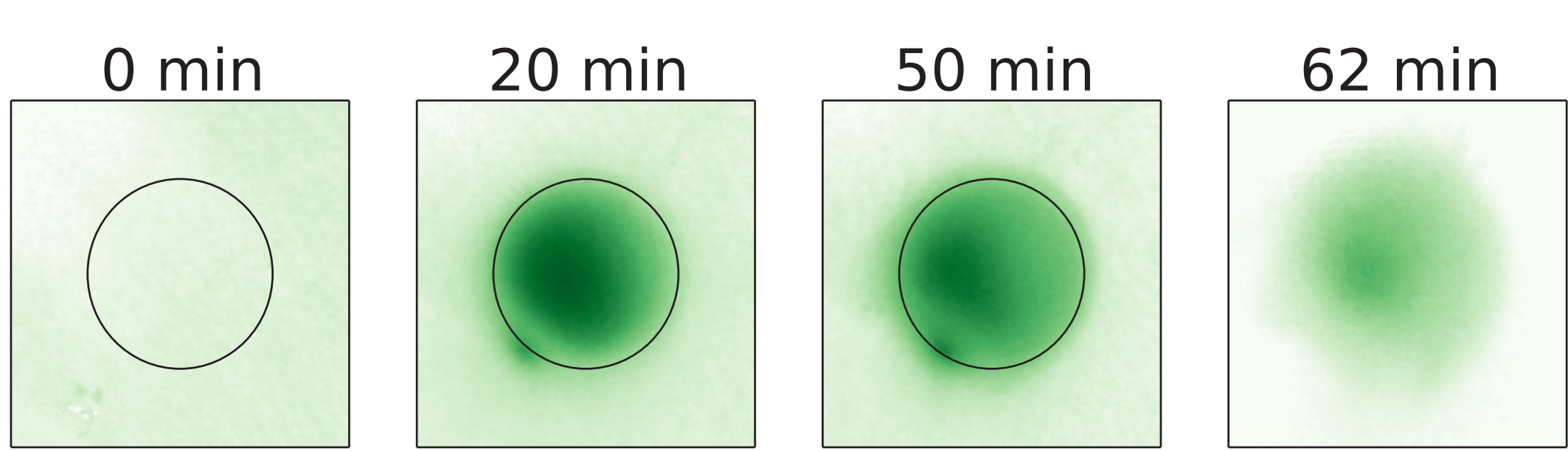

$70 \mathrm{~min}$

As a circular area is exposed to constant light, we measure:

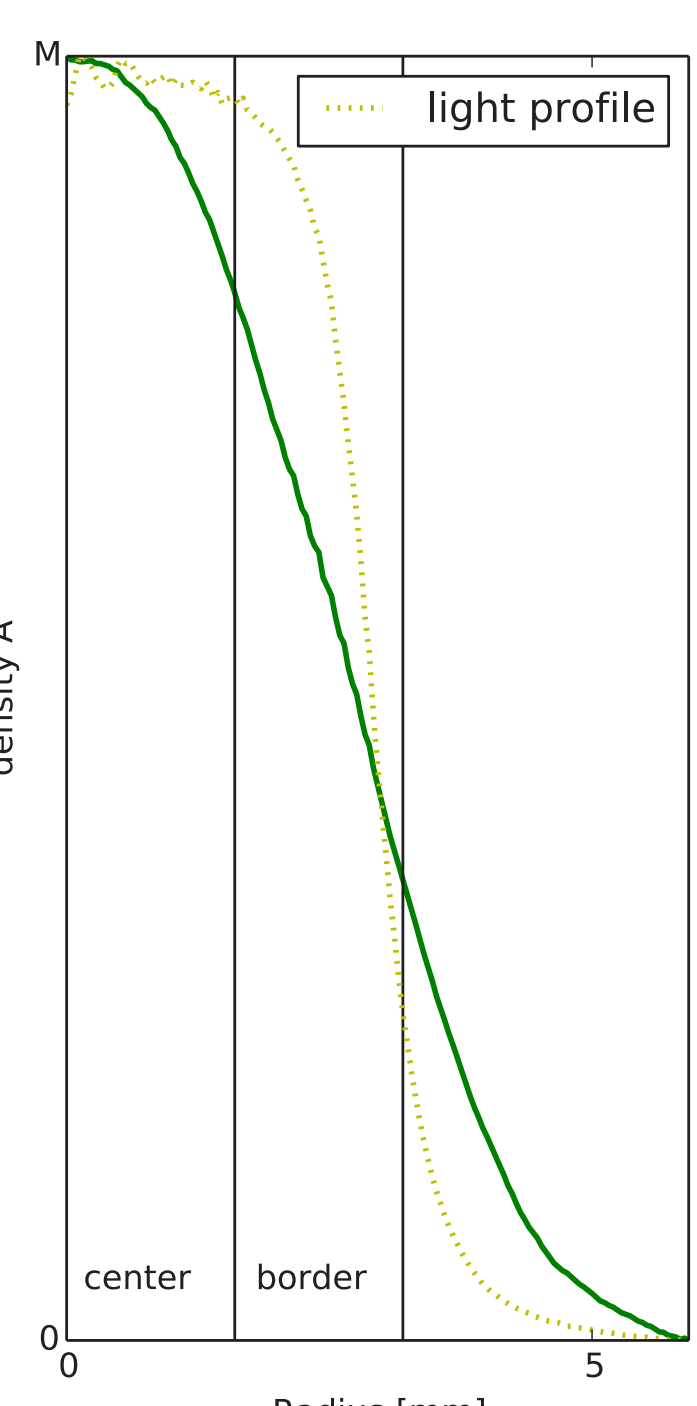

\begin{abstract}
- The sensitivity and the dynamic range of the algae from the density at the center $(A c)$ for various light intensities.

- The spatial resolution (s) as the slope on the border of the algae bump.

The formation time where the bump to reach maximal resolution and its persistence time.
\end{abstract}

\section{Micro level}

Other data from microscope recordings allows to get independent estimations for parameters of the model using single cell trajectories and population dynamics.
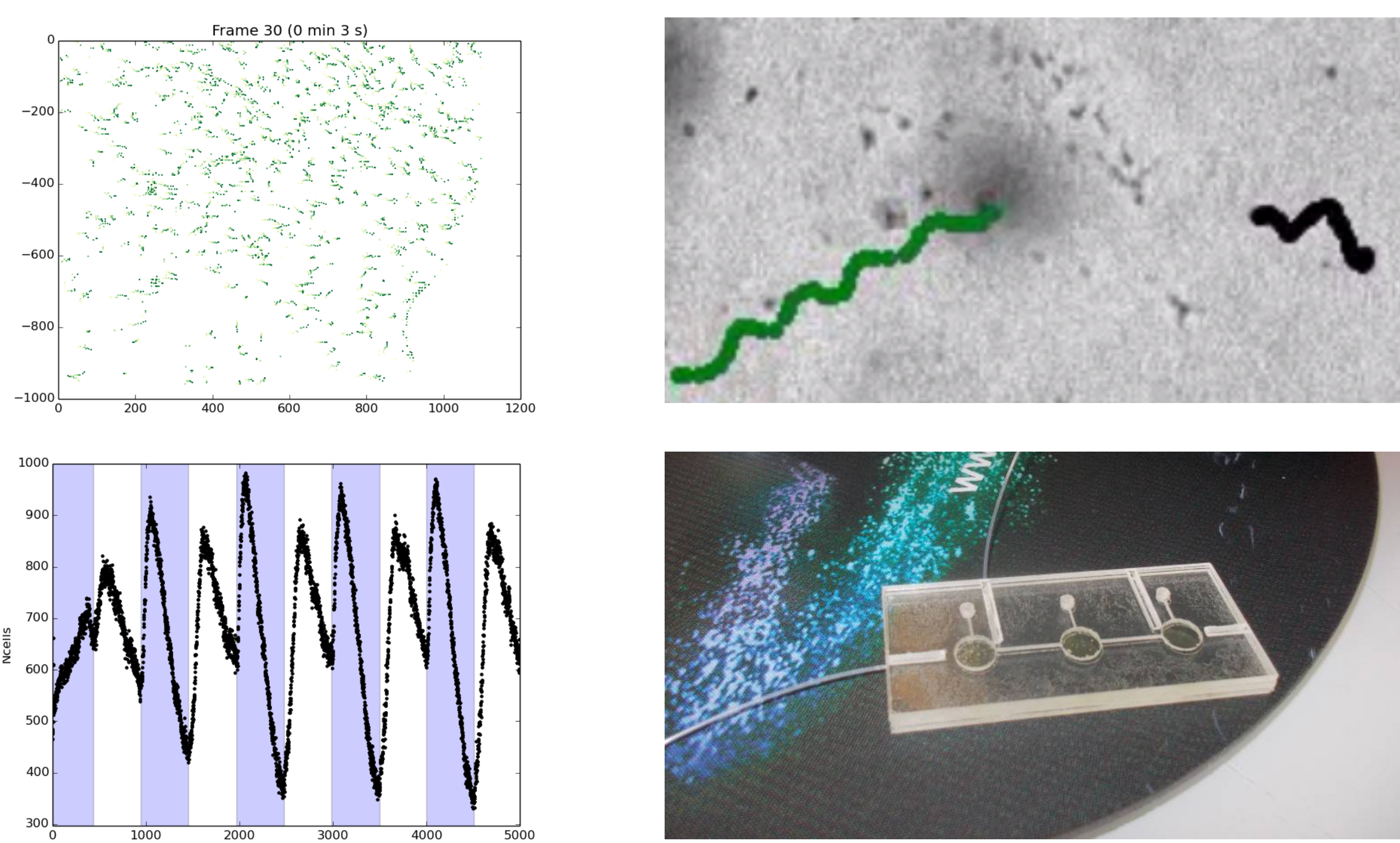

The variations in the number of cells in the field of view reflect the changes of position of the light source in the microchamber.

\section{Collective behavior}

At high density of cells, the interactions between individual behaviours leads to specific patterns of cell density, as shown here,

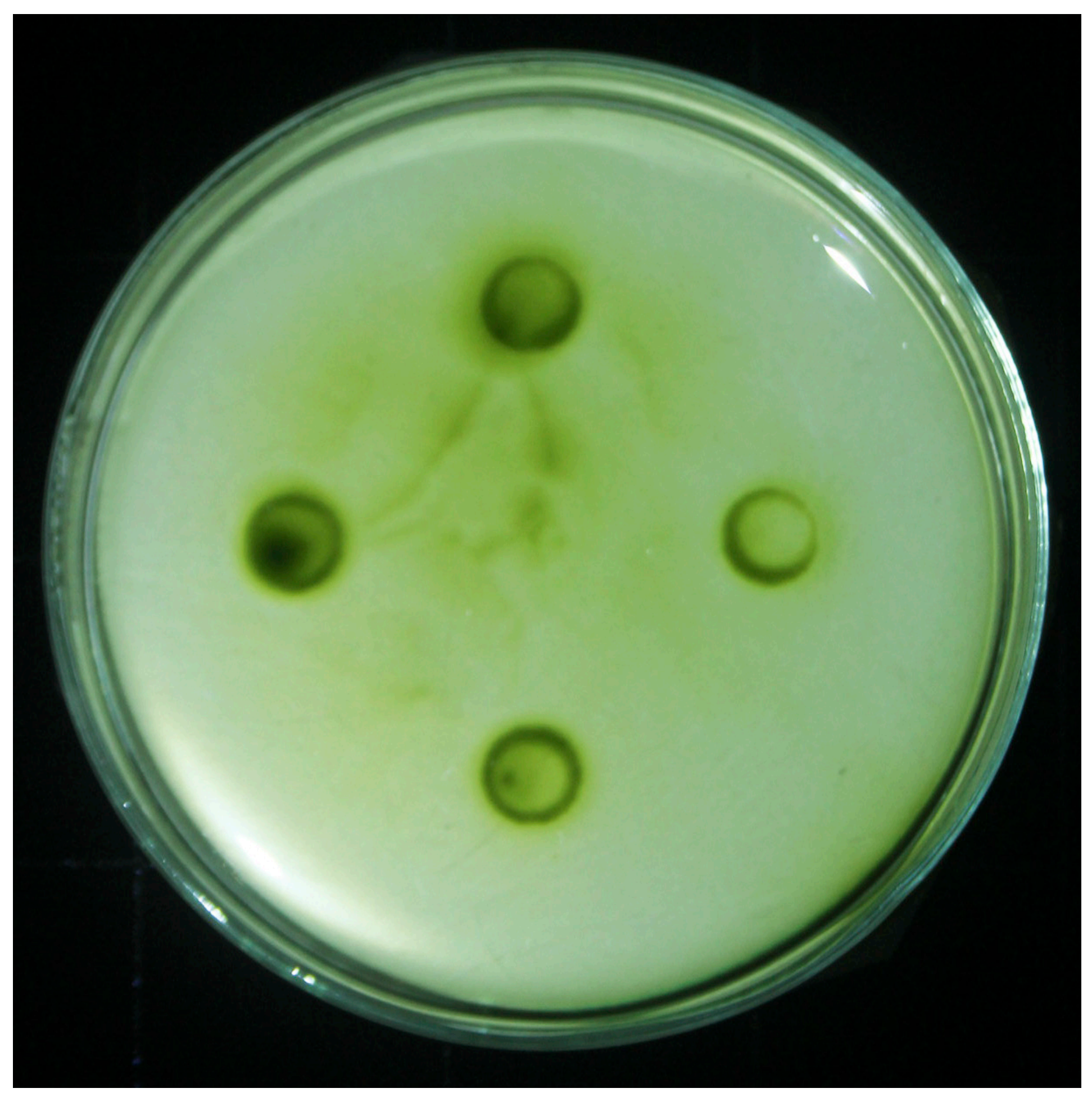

which could not be explained if cell trajectories are independent. See also «vortex» in bit.ly/1K7se2a

\section{References}

[1] Goldstein, Raymond E., Green Algae as Model Organisms for Biological Fluid Dynamics, Annual Rewiew of Fluid Mechanics, 2015

[2] Braitenberg, Valentino, Vehicles, Experiments in Synthetic Psychology, MIT Press, 1986

Measures of algae accumulation

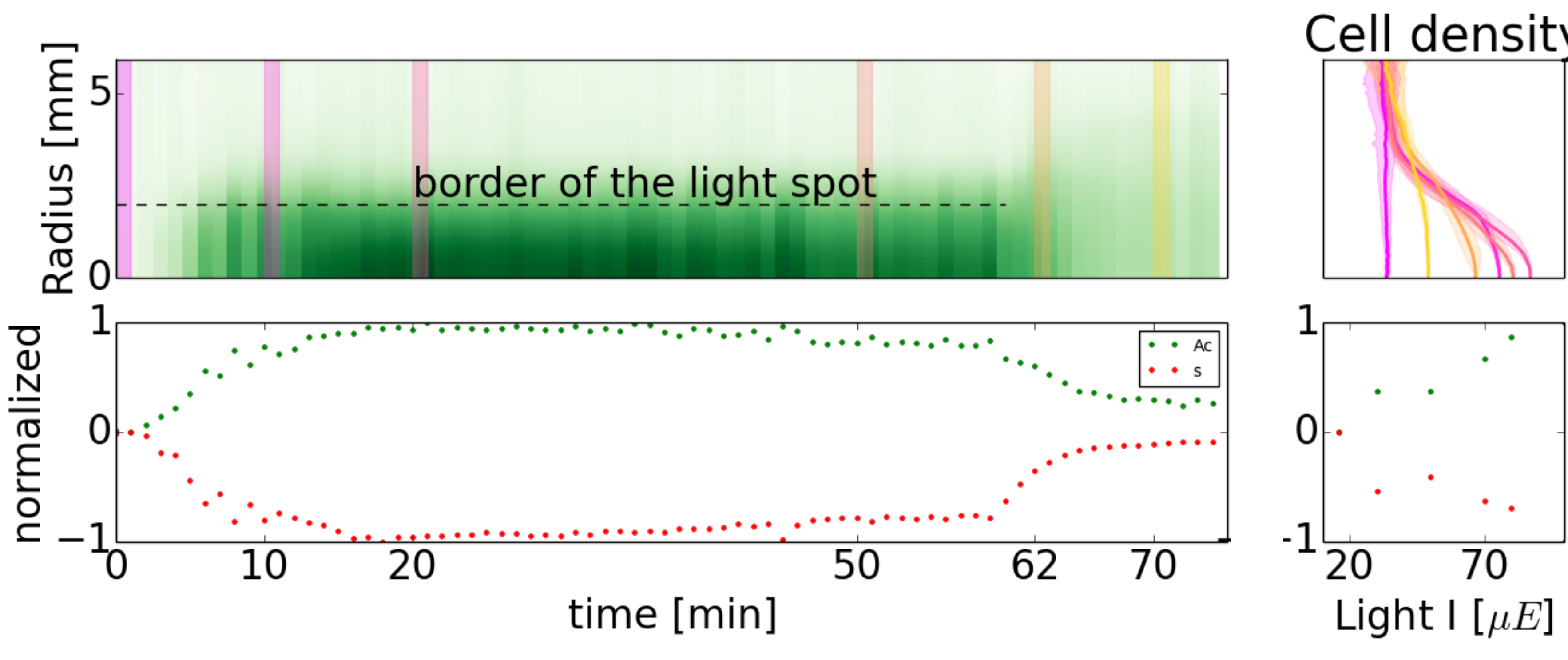

Dynamics and variation with light intensity of density at the center $A_{c}$ and spatial resolution s.
Models of phototaxis

Desynchronization in the beating of flagella

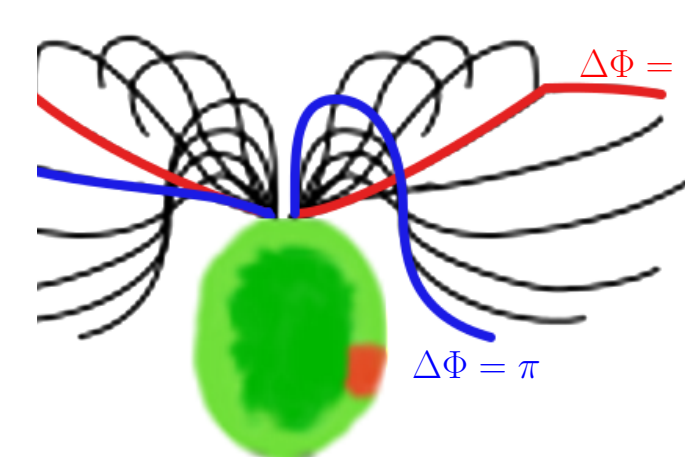

The dynamics of the 2 flagella (considered as oscillators) can be reduced to their phase difference $\varphi$ :

$$
d \phi_{t}=\left[\Delta \omega+K \sin \left(\phi_{t}\right)\right] d t+\sigma(I) d W_{t}
$$

- $\Delta \omega$ : the difference of beating frequency.

- $K$ : the coupling constant.

- $\sigma(I)$ : fluctuations due to the stochasticity of biochemica signals.

- I: Light intensity.

Population dynamics.

Run and Tumble trajectories

Transient desynchronizations generate rapid reorientations of the swimming path of algae at random times i.e.

$T \sim$ Poisson $\left(r_{I}\right)$

where the rate of the Poisson process depends on light intensity.
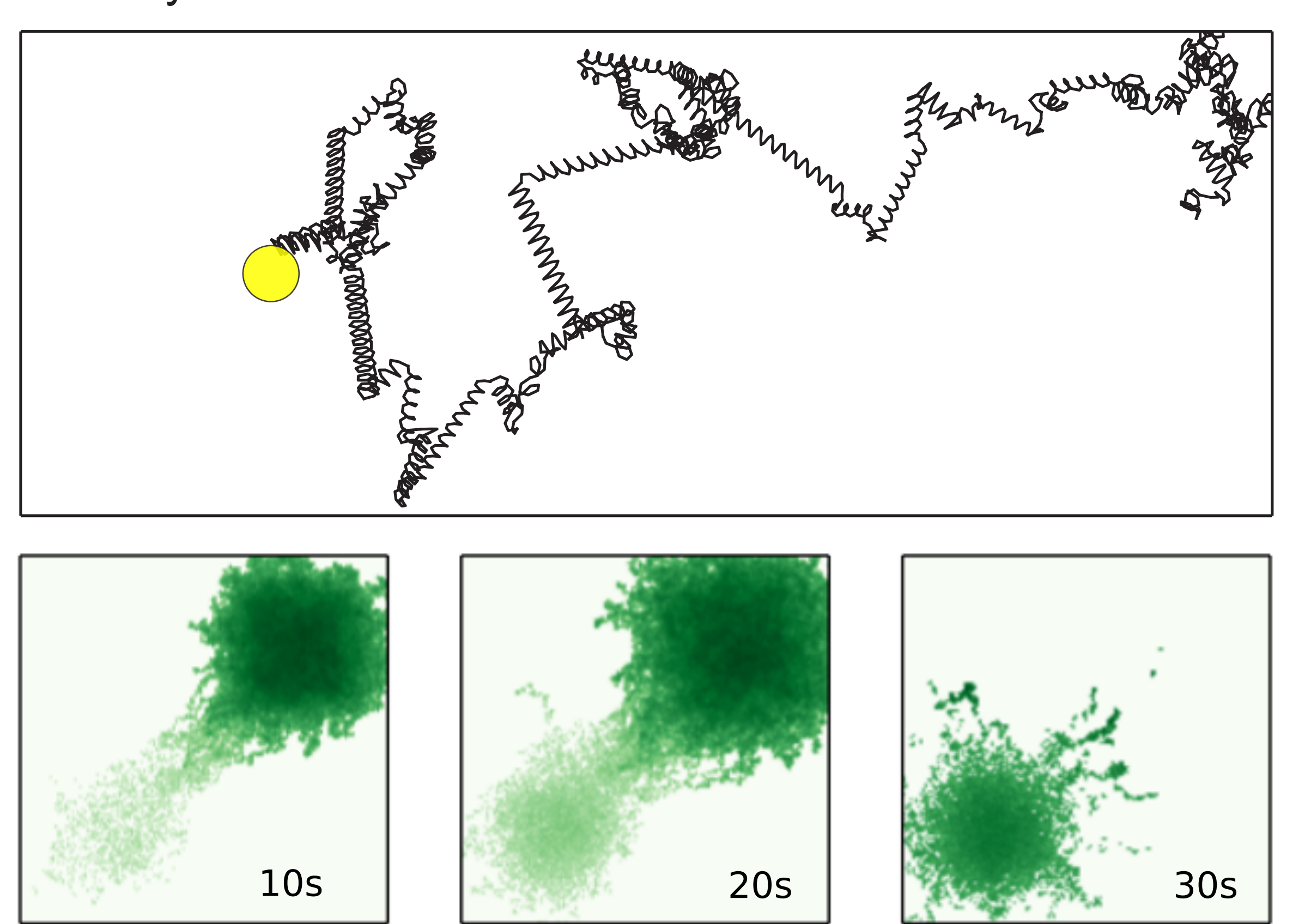
to the light source $\theta: r(l, \theta)=\frac{A}{1+e^{\alpha_{l} l-\alpha 2} \cos (\theta)-\beta}$

Macro and micro data will give us independent estimations of the diffusion coeffcient as well as the dependance of the tumbling rate on the light intensity. 